\section{Тетяна Потапчук,}

доктор педагогічних наук, професор, професор кафедри теорії та методики дошкільної та спеціальної освіти, ДВНЗ «Прикарпатський національний університет імені Василя Стефаника» (м. Івано-Франківськ, Україна)

\section{Tetiana Potapchuk,}

Doctor of Pedagogical Sciences (Ed.D.), Professor of the Department of Theory and Methods of Preschool and Special Education Vasyl Stefanyk Precarpathian National University (Ivano-Frankivsk, Ukraine) tatvolod@ukr.net ORCID ID 0000-0003-1680-6976

\section{Марія Клепар,}

доктор педагогічних наук, професор кафедри педагогіки початкової освіти ДВНЗ «Прикарапатський національний університет імені Василя Стефаника» (м.Івано-Франківськ, Україна)

\author{
Maria Klepar, \\ Doctor of Pedagogical Sciences, Professor of the \\ Department of Pedagogy of Primary Education, \\ Vasyl Stefanyk Precarpathian National University \\ (Ivano-Frankivsk, Ukraine) \\ mklepar10@gmail.com
}

ORCID ID 0000-0003-4923-8696

\title{
ТОЛЕРАНТНІСТЬ ТА ПЕДАГОГІКА ТОЛЕРАНТНОСТІ: ПРОБЛЕМИ НАУКОВИХ ДОСЛІДЖЕНЬ
}

Анотація. Стаття присвячена вивченню проблеми толерантності та педагогіки толерантності у наукових дослідженнях. Поняття «толерантність» визначається як принцип правового, соціально-політичного аспекту. Феномен «толерантність» 3 огляду на його інтегративний характер $€$ предметом вивчення різних наук: філософії, етики, політології, соціології, психології, культурології, педагогіки та ін. Насамперед відзначимо, що слово «толерантність» походить від латинського «toleгаnсіа», що має три значення: стійкість, витривалість; терпимість; допустиме відхилення. Ключовим змістом усіх цих слів є відсутність небажаної реакції індивіда в ситуації, коли вона можлива або практично вимушена. Толерантність зароджує довіру, готовність до компромісу та співпраці, а також радість, доброзичливість, комунікабельність. У загальному розумінні толерантність - це відсутність негативної реакції індивіда у всіх тих випадках, коли вона можлива та очікувана зовнішнім спостерігачем.

Педагогіка толерантності розглядає свободу як діяльність, що тісно пов'язана з поняттям «дисциплінованість». На думку вчених, мета виховання полягає в тому, щоб не втручатися в природній хід дозрівання дитини, а спостерігати за нею, допомагати її нормальному розвитку. Дослідники закликають орієнтуватися на самостійність і самодіяльність, шанобливо ставитися до дитини.

Мета статті - теоретично обґрунтувати поняття толерантності у наукових дослідженнях і дати визначення поняттю «педагогіка толерантності». Відповідно до мети дослідження було визначено такі завдання: проаналізувати теоретичні основи понять «толерантність» та «педагогіка толерантності»; розкрити сутність та особливості педагогіки толерантності.

Для розв'язання поставлених завдань використано теоретичні методи аналізу й узагальнення наукової та методичної літератури з досліджуваної проблеми.

Ключові слова: толерантність, педагогіка толерантності, ідеї гуманізації, культура спілкування, виховання толерантної особистості, гуманний педагогічний процес. 


\title{
TOLERANCE AND PEDAGOGY OF TOLERANCE: PROBLEMS OF SCIENTIFIC RESEARCH
}

\begin{abstract}
The article deals with the problem of scientific research. It is determined that tolerance is defined as the principle of legal, socio-political aspect. The phenomenon of "tolerance" in view of its integrative nature is the subject of study of various sciences: philosophy, ethics, political science, sociology, psychology, cultural studies, pedagogy, etc. First of all, let us note that the word "tolerance" comes from the Latin "tolgancia", which has three meanings: stability, endurance; tolerance; tolerance. The key content of all these words is the absence of an undesirable individual response in a situation where it is possible or almost forced. Tolerance breeds trust, a willingness to compromise and cooperation, as well as joy, goodwill, sociability. In the general concept, tolerance is the absence of a (negative) individual response in all cases where it is possible and expected by an outside observer.

It is revealed that tolerance pedagogy views freedom as an activity closely linked to the notion of discipline. According to scientists, the purpose of education is not to interfere with the natural course of maturation of the child, but to observe it, to help its normal maturation. Researchers urge to focus on autonomy and amateur activity, to respect the child respectfully.

It is stated that the pedagogy of tolerance implies: a culture of communication as an understanding of the other in dialogue, as a mutual understanding and empathy; tolerant thinking as a basis for knowing a person's personality, their needs, values, attitudes, beliefs and various forms of expression in the process of communication, which allow to nurture the personal qualities of the individual, transforming them in the direction of empathy, mutual respect, feelings of partnership. The basic principles of "Pedagogy of tolerance" are: cooperation on trust, psychological ecology, legal culture, "right to difference" (G. Shelamov). Ideas for the humanization of the educational and educational process, which are most widely covered in the pedagogy of cooperation (Sh. Amonashvili, E. Ilyin, V. Shatalov), are of fundamental importance for the pedagogy of tolerance. Innovative educators consider humane treatment of children, their needs, interests as the basis of pedagogical activity; accepting them as they are. Some aspects of the cultivation of tolerance are revealed by the "pedagogy of peace" (V. Mitina, A. Sirotenko). Summarizing some of the scientific and pedagogical achievements of these scholars, the essence of "pedagogy of peace" can be defined as: the formation of students outlook that would contribute to their preparation for participation in the construction of an independent democratic state - an equal member of the international community; teaching young people to live peacefully in the conflict world, to seek means of resolving conflicts without the use of force, to be active in maintaining peace on Earth; formation in the younger generation of conscious high responsibility for the fate of peace, preservation of life on the planet; respect for representatives of other nations, nationalities, ethnic groups; the desire for a full mutual understanding between all peoples.
\end{abstract}

The purpose of the study is to theoretically substantiate the notion of tolerance in scientific research and to identify the problem of research: pedagogy of tolerance. According to the purpose of the study, the following tasks were defined: to analyze the theoretical bases of the study of the concepts of "tolerance" and "pedagogy of tolerance"; to reveal the essence and features of pedagogy of tolerance.

The following theoretical methods were used to solve these problems: analysis and generalization of scientific and methodological literature on the problem under study.

Keywords: tolerance, pedagogy of tolerance, peace pedagogy, ideas of humanization, culture of communication, humane pedagogical process, education of tolerant personality.

\section{ВСТУП}

Постановка проблеми. Проблема толерантності для українського суспільства пов'язана, передусім, 3 необхідністю подолання внутрішньої роз'єднаності, у тому числі політичної, соціальної, релігійної, оскільки нетерпимість є однією з найбільших глобальних проблем сучасного світу. Виникає інтерес до явища толерантності, що розглядається як один із можливих шляхів подолання соціального напруження.

Виховання толерантності дає можливість пізнання культури різних народів, створюючи тим самим передумови взаєморозуміння і пошани, позиції співпраці, що є запорукою соціальної міжнаціональної стабільності. Основу сучасного освітнього простору має складати педагогіка толерантності, яка передбачає зміну системи людських відносин, побудову їх на взаємній повазі.

Аналіз наукових досліджень і публікацій. Актуальність дослідження підтверджується результатами вивчення наукової літератури з філософії, культурології, історії, соціології, психології і педагогіки толерантності. Науковцями толерантність визначається як принцип правового, соціально-політичного аспекту (М. Мчедлов), певна філософія (В. Лекторський), категорія відносин (О. Клєпцова, В. Маралов, В. Сітаров, О. Соколова, Г. Солдатова), толерантна свідомість (О. Асмолов, О. Газман, О. Грива, О. Кондаков, О. Насиновська), пізнавальна стратегія (А. Коржуєв, Н. Кудзієва, В. Попков, М.Поташник), основа свободи, поваги до прав іншої людини, терпимість, ненасильство, культура компромісу, діалог, особистісна або суспільна характеристика, яка припускає усвідомлення того, що світ і соціальне середовище багатомірні (В. Тішков). Водночас вихованню і навчанню толерантності все ще приділяється недостатньо уваги на всіх рівнях освітньо-виховної діяльності, у тому числі й у вищій школі. Окремі спроби в цьому напрямі зводяться переважно до проголошення локальних освітніх концепцій або організаційно-управлінських заходів.

Теоретичну основу дослідження становлять науково-теоретичні принципи і положення: сучасні соціальнофілософські дослідження з проблем толерантності (В. Лекторський, М. Мчедлов та ін.); психологія і педагогіка толерантності (О. Асмолов, О. Клєпцова та ін.); концепції представників гуманістичного напряму у вітчизняній педагогіці (К. Вентцель, В. Сухомлинський, К. Ушинський); педагогіка співпраці (Ш. Амонашвілі, О. Лисенкова, О. Полат, В. Шаталов), теорія полікультурного виховання (Г. Дмитрієв, А. Джуринський, Т. Менська).

\section{МЕТА I ЗАВДАННЯ ДОСЛІДЖЕННЯ}

Мета дослідження - теоретично обґрунтувати поняття толерантності та окреслити сутність проблеми дослідження - педагогіки толерантності. Відповідно до мети дослідження визначено такі завдання: 
проаналізувати теоретичні основи дослідження понять «толерантність» та «педагогіка толерантності»; розкрити сутність й особливості педагогіки толерантності.

\section{МЕТОДИ ДОСЛІДЖЕННЯ}

Для розв'язання поставлених завдань використано теоретичні методи аналізу й узагальнення наукової та методичної літератури з досліджуваної проблеми.

\section{РЕЗУЛЬТАТИ ДОСЛІДЖЕННЯ}

У педагогічній науці феномен «толерантність» розглядається як: 1) особистісна якість, ознака гуманної людини або 2) один із принципів гуманістичного виховання» (Кремень В. Г., 2008, с. 912).

У дисертації О. Волошиної «Педагогічні умови виховання толерантності у підлітків старшого віку в позакласній роботі» проаналізовано зарубіжний і вітчизняний досвід толерантного виховання учнівської молоді. На думку автора, важливою умовою розвитку толерантності учнів $€$ створення толерантного виховного простору. Під толерантним простором О. Волошина розуміє організацію та реалізацію взаємостосунків усіх суб'єктів навчально-виховного процесу, побудованих на принципах толерантності та спрямованих на ділове, безконфліктне спілкування й моральне виховання учнів (Волошина О. В., 2007).

Дисертація Е. Койкової присвячена проблемі виховання толерантності у молодших школярів на уроках музики в умовах полікультурного простору. Науковець вважає музичне мистецтво провідним засобом виховання толерантності дітей молодшого шкільного віку, оскільки воно здатне за допомогою емоційної дії та рефлексії впливати на особистісне ставлення однієї людини до іншої (Койкова Е. І., 2008).

Б. Вульфов розуміє толерантність як «здатність людини (або групи) співіснувати з іншими людьми (спільнотами), яким властивий інший менталітет, образ життя» (Вульфов Б. 3., 2002, с.12). Він указує на те, що ця здатність формується в кожної людини як істоти соціальної, у кожної спільноти, яка безперечно «стикається» 3 іншими спільнотами (там само, с. 12).

Дослідниця В. Нечерда розглядає толерантність як складну морально-етичну якість особистості, що виявляється в розумінні розмаїття й неоднозначності цього світу, а також у ціннісному ставленні й позитивній взаємодії людини з навколишньою дійсністю і характеризується психологічною готовністю та здатністю людини до розуміння та співробітництва з іншими людьми, її повагою до різноманітних прав і свобод інших членів світової спільноти, визнанні їх рівності та рівноцінності (Нечерда В. Б., 2014, с. 221). Аналізуючи комплекс якостей толерантної особистості, Н. Нечерда виокремлює такі: терпимість, упевненість у собі, силу волі, самовладання, рефлективність, емпатію, доброзичливість, довіру, чуйність, гнучкість, гуманність, альтруїзм, почуття гумору (там само, с. 52-53).

Науковець М. Горват здійснила ретроспективний аналіз категорії «толерантність», короткий екскурс в історію дослідження цієї проблеми в більшості країн світу, розробила модель виховання толерантності в умовах інтерактивного педагогічного спілкування, що складається з таких блоків: цільового (мета, завдання); змістового (сутнісна характеристика інтерактивного педагогічного спілкування як умови виховання толерантності молодших школярів, педагогічні умови); операційного (форми, методи, засоби, спрямування, стилі, переконання) і результативного (критерії, рівні, очікуваний результат) (Горват М. В., 2014).

У педагогічній науці педагогіку толерантності визначають як систему педагогічних принципів, методів, прийомів, форм роботи педагога. Основними положеннями педагогіки толерантності є визнання й прийняття дитини такою, якою вона є, повага до особистості школяра, співпраця, взаємодія педагога й учня, розвиток творчих здібностей, самореалізація.

Дослідники В. Маралов, В. Сітаров розглядають педагогіку толерантності в контексті ідей «педагогіки ненасильства», яка має вирішити низку завдань, а саме: виховання миролюбства, поваги прав і гідності інших людей, бережливого ставлення до всього живого, вирішення конфліктів без використання відкритих і прихованих форм примушування (Маралов В. П., Ситаров В. А., 1998., с. 68-96). Отже, ідеї педагогіки ненасильства співзвучні з ідеями педагогіки толерантності.

Ш. Амонашвілі розробив систему гуманного педагогічного процесу, спрямованого на розвиток і виховання толерантної особистості. Наведемо основні принципи, розроблені педагогом щодо гуманістичного виховання дітей: 1) виявляйте живий інтерес до життя дитини, до її радощів, прагнень, невдач, до їі особистісних переживань; 2) за необхідності сприяйте, допомагайте, висловлюйте їй співчуття; 3) спілкуйтеся з дитиною, як з дорослим, від якого очікують взаємної довіри, поваги, розуміння; 4) встановлюйте з кожною дитиною особисті, довірливі взаємини, виказуйте довіру та щирість до неї (Амонашвили Ш. А., 1995, с. 200-203).

Відтак формула гуманістичної педагогіки «прийняти - зрозуміти - допомогти - любити - співчувати - радіти успіхові дитини - надихати» стала основою педагогіки толерантності (Голованова Н. Ф., 2003, с.1 - 9).

У цьому контексті вирішення проблеми Бетті Е. Рієрдон розробив напрями педагогічної діяльності у процесі навчання толерантності:

1. Толерантність. Визнання прав інших на життя і гідність.

2. Впізнання. Доброзичливе усвідомлення присутності в своєму соціальному середовищі представників інших культур.

3. Ставлення до розбіжностей. Визнання позитивних аспектів різноманітності.

4. Розуміння унікальності. Вміння цінувати конкретні прояви своєрідності і різноманітності людей.

5. Додатковість як принцип відношення до розбіжностей. Здатність поєднувати розбіжності так, щоб вони збагачували і зміцнювали суспільство.

6. Взаємність як основа прагнення до співробітництва. Здатність бачити загальні, взаємовигідні для різних груп цілі й інтереси та досягати їх здійснення. 
7. Культура світу. Визнання взаємозалежності людського існування й універсальності ряду цінностей, докладання зусиль із конструктивної взаємодії різних соціокультурних груп (Кузьмина Н. В., 1970, с. 52-53).

Педагогіка толерантності передбачає: культуру спілкування як розуміння іншого у діалозі, як взаєморозуміння та співпереживання; толерантне мислення як основа пізнання індивідуальності людини, її потреб, цінностей, поглядів, переконань та різноманітних форм виявлення в процесі спілкування, що дозволяють виховувати особистісні якості індивіда, трансформуючи їх у бік емпатії, взаємоповаги, почуття партнерства.

Основними принципами педагогіки толерантності, за Г. Шеламовою, є: співпраця за довірою, психологічна екологія, правова культура, «право на відмінність» [Безюллва Г. В. Шеламова Г. М., 2003, с. 86-87).

Для педагогіки толерантності провідне мають ідеї гуманізації навчально-виховного процесу, які найширше висвітлюються у педагогіці співробітництва (Ш. Амонашвілі, Є. Ільїн, В. Шаталов). Педагоги-новатори вважають основою педагогічної діяльності гуманне ставлення до дітей, їхніх потреб, інтересів; прийняття їх такими, якими вони є.

Особливе значення у контексті педагогіки толерантності має концепція М. Монтессорі (Монтессорі М., 1999), сутність якої становить положення про те, що школа повинна надавати простір вільним проявам особистості дитини. М. Монтессорі розглядає свободу як діяльність, що тісно пов'язана з поняттям «дисциплінованість». На її думку, мета виховання полягає в тому, щоб не втручатися в природній хід дозрівання дитини, а спостерігати за нею, допомагати ї̈ нормальному розвитку. Дослідниця закликала орієнтуватися на самостійність і самодіяльність, шанобливо ставитися до дитини.

Принципове значення для педагогіки толерантності мають погляди Л. Толстого. Свобода розглядається ним як пріоритетний принцип навчання і виховання. Під свободою Л. Толстой розуміє ненасильницький вплив однієї людини на іншу з метою формування у вихованця моральних звичок та якостей особистості (Толстой Л., 1993, с. 85).

Дослідники М. Кабатченко (Кабатченко М. В., 1993, с. 109-110), В. Мітіна (Митина В. С., 1987, с.112-115), А. Сиротенко (Сиротенко А. Й., 1987) розглядають проблему виховання толерантності у контексті ідей «педагогіки миру». Узагальнюючи окремі науково-педагогічні доробки цих учених, суть «педагогіки миру» можна визначити як: формування в учнів світогляду, який сприяв би їхній підготовці до участі в будівництві незалежної демократичної держави - рівноправного члена міжнародного співтовариства (С. Дем'янчук); навчання молоді мирно жити в конфліктному світі, шукати засоби виходу з конфліктів без використання сили, бути активними в справі підтримки миру на Землі; формування у підростаючого покоління усвідомленої високої відповідальності за долю миру, збереження життя на планеті; повага до представників інших націй, народностей, етнічних груп; прагнення до встановлення повного взаєморозуміння між усіма народами (Дейнеко О. А., 1983), (Кабатченко М. В., 1993, с. 109-110), (Митина В. С., 1987, с. 112-115).

Науковець К. Хіттєн зазначає, що у західних демократіях, і перш за все, в таких багатоетнічних державах, як Канада і США, підійшли до декларування рівноправності та рівноцінності найрізноманітніших самобутностей. Автор зауважує, що це було пов'язано з прийнятими тут демократичними імперативами, які проголошували, що плюралізм $€$ цінним для всього суспільства (Хиттэн К., 1996, с. 114).

Однак і тут існують проблеми. М. Уолцер стверджує, що проголошена в такому суспільстві соціальна рівність постійно зводиться нанівець економічною нерівністю, в якій знаходяться різні культурні групи (Уолцер М., 2000, с. 124).

П. Степанов розглядає толерантність «як ціннісне ставлення людини до людей, яке виражається у визнанні, прийнятті та розумінні ним представників інших культур. Визнання - це здатність бачити в людині іншої культури носія інших цінностей, інших поглядів, іншого способу життя, а також усвідомлення його права бути іншим. Прийняття - це позитивне ставлення до його іншості. Розуміння - це здатність поглянути на світ його очима, з його точки зору» (Степанов П. В., 2005, с. 5).

О. Савченко визначає толерантність як соціальну і особистісну цінність, «як усвідомлення особою необхідності доброзичливого або стриманого ставлення до відмінностей між людьми у широкому розумінні, уникнення нетерпимості, поціновування різноманітності у природі, культурі, релігії, у людських стосунках» (Савченко О., 2014, с.5). Наголошуючи на визначній ролі педагога у формуванні толерантності, дослідниця зазначає, що толерантний педагог «має уникати крайнощів націоналізму й етноцентризму, а натомість цілеспрямовано формувати у вихованців терпимість, безконфліктність, національну ідентичність і повагу до культур інших народів» (там само, с. 5).

М. Красовицький, розмірковуючи про проблему формування толерантної особистості, акцентує увагу на поширення в середовищі школярів таких негативних тенденцій, як нездатність до плідного співробітництва, невміння зіставляти свої дії та вчинки з інтересами інших людей; обмеження в проявах або повна відсутність таких почуттів, як співпереживання, відчуття болю іншої людини; розшарування учнів у колективі за одягом, матеріальним становищем, посадою батьків тощо; прояви жорстокості, черствості, байдужості один до одного та нейтральне чи схвальне ставлення до вчинків такого характеру. Все це, на думку вченого-педагога, призводить до деформування поглядів, втрати моральних якостей школярів (Красовицький М.Ю., 1998).

\section{ВИСНОВКИ ТА ПЕРСПЕКТИВИ ПОДАЛЬШИХ ДОСЛІДЖЕНЬ}

Аналіз наукової літератури з проблеми дослідження дозволяє уточнити сутність поняття «толерантність» як інтегрованого морально-особистісного утворення, в основі якого лежить ціннісне ставлення до інших, до себе, навколишнього середовища, яке виявляється у терпимому ставленні до інтересів, думок, поглядів, звичок, вірувань інших людей, незалежно від їх поглядів, національності та релігійної приналежності. Педагогіка толерантності виступає за визнання прав дитини, акцентує увагу на створенні природної атмосфери співпраці між учителем і учнем, яка повністю виключає примус, а основними моральними якостями вчителя вважає любов до педагогічної праці та любов до дітей. На формування толерантності впливають такі чинники: виховання, досвід, спілкування, культура, цінності, потреби, інтереси, характер, темперамент, звички, емоційність та тип поведінки особистості. Отже, виховання толерантності у молодого покоління - складний і багатогранний процес. 
Проведене дослідження не вичерпує всіх аспектів окресленої проблеми. Подальшого вивчення і розвитку потребує, зокрема, питання виховання толерантності у різних вікових групах (особливо у студентської молоді).

\section{СПИСОК ВИКОРИСТАНИХ ДЖЕРЕЛ}

Амонашвили, Ш. А. (1995). Размышления о гуманной педагогике. М. : Издательский дом Ш. А. Амонашвили.

Безюллва, Г. В., Шеламова, Г. М. (2003). Толерантность: взгляд - поиск - решение. М.: Вербум.

Волошина, О. В. (2007). Педагогічні умови виховання толерантності у підлітків старшого віку в позакласній роботі: дис. ... канд. пед. наук : спец. 13.00.07 «Теорія і методика виховання». Вінниця.

Вульфов, Б. 3. (2002). Воспитание толерантности: сущность и средства. Внешкольник, 6, 12 - 16.

Голованова, Н. Ф. (2003). Особенности технологии воспитательной работы в начальной школе. Начальная школа плюс до и после, 3, 1-9.

Горват, М. В. (2014). Виховання толерантності у молодших підлітків в умовах інтерактивного педагогічного спілкування : дис. ... канд. пед. наук : спец. 13.00.07 «Теорія і методика виховання». Умань.

Дейнеко, О. А. (1983). Рационализация труда руководителя. М. : Знание.

Енциклопедія освіти (2008) / Акад. пед. наук України; головний ред. В. Г. Кремень. К. : Юрінком Інтер.

Кабатченко, М. В. (1993). Воспитание в духе мира, социальной ответственности, сотрудничества. Материалы международного педагогического проекта Р.Е.Р.С.Е.: Центр педагогики мира. Москва.

Койкова, Е. І. (2008). Виховання толерантності у молодших школярів на уроках музики в умовах полікультурного простору: дис. ... канд. пед. наук : 13.00.07. РВНЗ «Крим. гуманіт. ун-т» (м. Ялта). Луганськ.

Красовицький, М. Ю. (1998). На власні очі: проблеми морального виховання учнів у теорії і практиці вітчизняної та американської педагогіки. Ін-т педагогіки АПН України. К. : Педагогічна думка.

Кузьмина, Н. В. (1970). Методы исследования в педагогической деятельности. М.: Изд-во Лгу, 1970.

Маралов, В. П., Ситаров, В. А. (1998). Проблемы ненасилия в религиозных и педагогических концепціях. Педагогика толерантности, 3-4, 68-96.

Митина, В. С. (1987). Педагоги - за предотвращение ядерной войны. Советская педагогика, 2, $112-115$.

Монтессори, М. (1999). Антология гуманной педагогики / сост. М.В. Богуславский, Г.Б. Корнетов. М : Издательский дом Ш.А. Амонашвили, Московский городской педагогический университет.

Нечерда, В. Б. (2014). Педагогічні умови виховання толерантності у старших підлітків у навчально-виховному процесі загальноосвітньої школи : дис. ... канд. пед. наук : 13.00.07. К., Ін-т проблем виховання НАПН України.

Савченко, О. (2014). Толерантність як цінність шкільної освіти: методичний аспект. Початкова школа, 9, 4-7.

Сиротенко, А. Й. (1987). Уроки миру в школі. К. : Знання УРСР.

Степанов, П. В. (2005). Воспитание толерантности у школьников: теория, методика, диагностика / П. В. Степанов; под ред. Л. И. Новиковой. М. : АПК и ПРО.

Толстой, Л.Н. (1993). Путь к жизни. М. : Республика.

Уолцер, М. (2000). О терпимости. Москва.

Хиттэн, К. (1996). Культура и педагогика: о книге Янга Пэя «Культурные основы образования». Новые ценности образования, 4, 4-122.

\section{REFERENCES}

Amonashvili, Sh. A. (1995). Reflections on humane pedagogy. M.: Sh. A. Amonashvili Publishing House.

Bezyullova, G.V., Shelamova, G.M. (2003). Tolerance: look - search - solution. M.: Verbum.

Voloshina, O.V. (2007). Pedagogical conditions of education of tolerance in older adolescents in extracurricular work: dis. ... Cand. ped. Sciences: Special. 13.00.07 Theory and Methods of Education. Vinnitsa.

Wulfov, B.Z. (2002). Educating tolerance: essence and means. Extracurricular, 6, 12-16.

Golovanova, N.F. (2003). Features of technology of educational work in elementary school. Elementary school plus before and after, 3, 1-9.

Horvat, M.V. (2014). Upbringing of tolerance in younger adolescents in conditions of interactive pedagogical communication: diss. ... cand. ped. sciences: Special. 13.00.07 / Theory and Methods of Education. Uman.

Deineko, O.A. (1983). Rationalization of the work of the manager. M.: Knowledge.

Kabatchenko, M.V. (1993). Education in the spirit of peace, social responsibility, cooperation. Materials of the international pedagogical project rerese: Center for pedagogy of the world. M.

Koikova, E.I. (2008). Upbringing of tolerance among younger students in music lessons in the conditions of multicultural space: diss. ... Cand. ped. Sciences: 13.00.07. Regional Crimea. humanite. un-t "(Yalta). Lugansk.

Krasovytskyy, M. Yu. (1998). With your own eyes: problems of moral education of students in the theory and practice of national and American pedagogy. Institute of Pedagogy of the Academy of Pedagogical Sciences of Ukraine. K.: Pedagogical Thought.

Kuzmina, N.V. (1970). Research methods in pedagogical activity. M .: Publishing House of LSU.

Maralov, V.P., Sitarov, V.A. (1998). Problems of nonviolence in religious and pedagogical concepts. Pedagogy of tolerance, 3-4, 68-96.

Mitina V.S. (1987). Educators - for the prevention of nuclear war. Soviet Pedagogy, 2, 112-115.

Montessori, M. (1999). Anthology of humane pedagogy / comp. M.V. Boguslavsky, G.B. Cornets. M: ShA Publishing House Amonashvili, Moscow City Pedagogical University.

Necherda, V.B. (2014). Pedagogical conditions for the cultivation of tolerance in older adolescents in the educational process of a comprehensive school: diss. ... Cand. ped. Sciences: 13.00.07. K., Inst. Of Problems of Education of the National Academy of Pedagogical Sciences of Ukraine.

Savchenko, O. (2014). Tolerance as a value of school education: a methodical aspect. Elementary School, 9, 4-7.

Syrotenko, A.I. (1987). The lessons of peace in school. K.: Knowledge of the USSR. Stepanov, P.V. (2005). The education of tolerance in schoolchildren: theory, methodology, diagnostics / P.V. Stepanov; ed. L.I. Novikova. M.: AIC and missile defense.

Tolstoy, L.N. (1993). The way to life. M.: Republic.

Walzer, M. (2000). On tolerance. M.

Hitten, K. (1996). Culture and Pedagogy: Young Pay's book The Cultural Foundations of Education. New values of education, 4, 4-122.

Статтю подано до редколегії 04.03.2020 p.

Рекомендовано до друку 25.03.2020 p. 